\title{
Burnishing Operation for Corrosion Resistance Improvement of AISI 1017 Carbon Steel
}

\author{
Zeyad D. Kadhim, Mohammed A. Abdulrazzaq, Suha Q. AL-Shahrabalee
}

\begin{abstract}
This research deal with investigation the influence of burnishing operation on the corrosion resistance of low carbon steel. The burnishing operation involve pressing a hard roller made from stainless steel on the surface of the rotatory shaft, this operation leads to the formation of a plastic deformation on the surface of the steel. Burnishing feed and burnishing speed were the variables which are used for this study. The first group involve hold burnishing speed on $125 \mathrm{rpm}$ with variable feeds of $0.6,0.9,1.5,2$ and $3 \mathrm{~mm} / \mathrm{rev}$ and the second group involve hold burnishing feed on $2 \mathrm{~mm} / \mathrm{rev}$ with variable speed of $85,125,370,800$ and 1200rpm. The corrosion test was done via applying potentiostat at $23^{\circ} \mathrm{C}$ in sample of water from Tigress River at upstream Samara'a barrage and groundwater (Yousifia salt well $90 \mathrm{~m}$ below ground surface). The result showed that there was improvement in corrosion resistance of the steel were the corrosion rate reduced from $7.577 \mathrm{mpy}$ to $0.685 \mathrm{mpy}$ in sample of water from Tigress River and from 8.878 mpy to 1.38 mpy sample of water from groundwater.
\end{abstract}

Index Terms-Carbon Steel; Corrosion Resistance; Burnishing Operation.

\section{INTRODUCTION}

Most metallic materials experience interaction with surroundings. Frequently, these interactions damage a material's utility and lead to deterioration of its appearance, mechanical properties (e.g., strength and ductility), physical and other properties. Mechanisms of deteriorative are differ from material to other. In metallic materials, there is loss in material either via the formation of nonmetallic film (oxidation), scale or by dissolution (corrosion) [1], [2]. Corrosion is the result of the deterioration of alloys or metals as a result of revers interaction with surrounding environment [3], [4]. The driving force for a material to oxidize is its free energy of oxidation and when the material reacts with oxygen, this energy will be released [5], [6].

Steel as an alloy of iron and carbon is regarded common engineering material and it is applied in a wide range of application like appliances and automobile and play a major role in machine design for base plates, chutes, housings, structural members and countless machine components [7], [8]. Low carbon steel has carbon content of $0.15 \%$ to $0.35 \%$, and it is the most common form of steel as it provides material properties that are acceptable for many

Published on June 26, 2018

Z. D. Kadhim ,Asst. Prof., Materials Engineering Department, AlMustansiriyah University, Baghdad, Iraq

M. A. Abdulrazzaq, Doctor, Mechanical Engineering Department, AlMustansiriyah University, Baghdad, Iraq

S. Q. AL-Shahrabalee , Engineer, Materials Engineering Department, Al-Mustansiriyah University, Baghdad, Iraq (e-mail: suhaqais88@ gmail.com). applications. It is neither externally brittle nor ductile because of its lower $\mathrm{C}$ content. It has lower tensile strength and is malleable [9], [10].

Burnishing process can be defined as a cold working operation where the plastic deformation happens via applying a pressure throw a ball or roller on the surface of metal as indicated in Fig. 1 and because of this it will lead to improve the properties of metal. This operation will make the surface harder and smoother, generating a finished which will last longer than the material that has not been cold worked via burnishing operation [11], [12]. All machined surfaces have sequences of valleys and peaks of irregular spacing and height, the plastic deformation produced via roller burnishing operation is a displacement of the metal in the peaks into the valleys under pressure. This result in work hardened, tough, corrosion and wear resistance surface [13], [14].

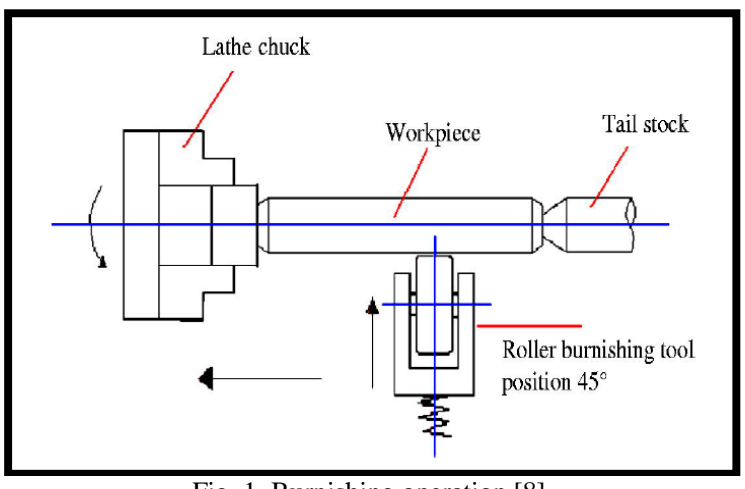

Fig. 1. Burnishing operation [8]

\section{IMPORTANT FACTORS THAT EFFECT ON BURNISHING PROCESS RESULTS}

1. Number of passes which used in burnishing operation.

2. Burnishing speed.

3. Feed rate.

4. Size of burnishing tool.

5. Depth of penetration [15], [16].

\section{BENEFITS OF BURNISHING OPERATION}

1. Simple process which can be accomplished via conventional machines (like lathe machine).

2. When compared with other operations, tool wear is moderately less.

3. Provides close-fitting dimensional tolerances.

4. Doesn't produce dust, shavings, chips, turnings or filings. 
5. Perhaps replace complex operations like lapping, honing and grinding.

6. Requires low torque and energy since the load of pressure is relatively low [17], [18].

\section{EXPERIMENTAL WORK}

Low carbon steel is the metal which was applied for this study. The metal was analysis chemically via Thermo ARL 3460 , optical emission spectrometer at a moister rate of $25 \%$ and $25.5^{\circ} \mathrm{C}$ and by contrast the results with American standard it was evident that it was type (AISI 1017) carbon steel as demonstrated in Table I.

\begin{tabular}{ccc} 
TABLE I: CHEMICAL COMPOSITION OF THE USED STEEL \\
\hline \hline Elements & Actual value & Standard value \\
\hline Fe $\%$ & Bal. & $99.11-99.56$ \\
$\mathrm{C} \%$ & 0.174 & $0.14-2.0$ \\
$\mathrm{Si} \%$ & 0.185 & - \\
$\mathrm{Mn} \%$ & 0.585 & $0.3-0.60$ \\
$\mathrm{P} \%$ & 0.009 & $\leq 0.040$ \\
$\mathrm{~S} \%$ & 0.022 & $\leq 0.050$ \\
$\mathrm{Cr} \%$ & 0.165 & - \\
$\mathrm{Mo} \%$ & 0.009 & - \\
$\mathrm{Ni} \%$ & 0.062 & - \\
$\mathrm{Al} \%$ & 0.021 & - \\
$\mathrm{Cu} \%$ & 0.130 & - \\
$\mathrm{V} \%$ & 0.001 & - \\
$\mathrm{W} \%$ & 0.046 & \\
\hline \hline
\end{tabular}

The steel was obeyed to stress relive treatment via placing it in furnace at a temperature of $200^{\circ} \mathrm{C}$ for three hours to relieve stresses as demonstrated in Fig. 2.

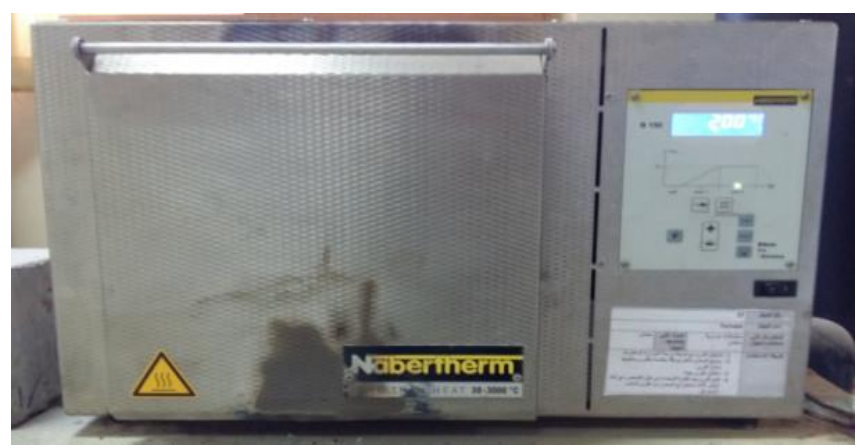

Fig. 2. The electric furnace applied for stress relieve treatment

\section{A. Microstructure test}

1. The specimens were grinding via applying grinding machine, the abrasive papers were replaced in device to grinding the sample gradually and the papers which were used in grinding were $(400,800$, $1000,1200,1500,1700$ and 2000) respectively.

2. After grinding process, polishing operation were carried out by applying gloss cloth with diamond paste for polishing the sample.

3. the specimen was immersed for 20 second in etching solution (consist from $2 \% \mathrm{HNO}_{3}$ acid and 98\% Methanol alcohol) then it was washed with distilled water and dried out to be ready for microstructure examination

4. Via optical microscopic at X200 the microstructure of the steel without surface treatment was seen. It consists of light region (ferrite) and dark region (pearlite). As shown in Fig. 3.

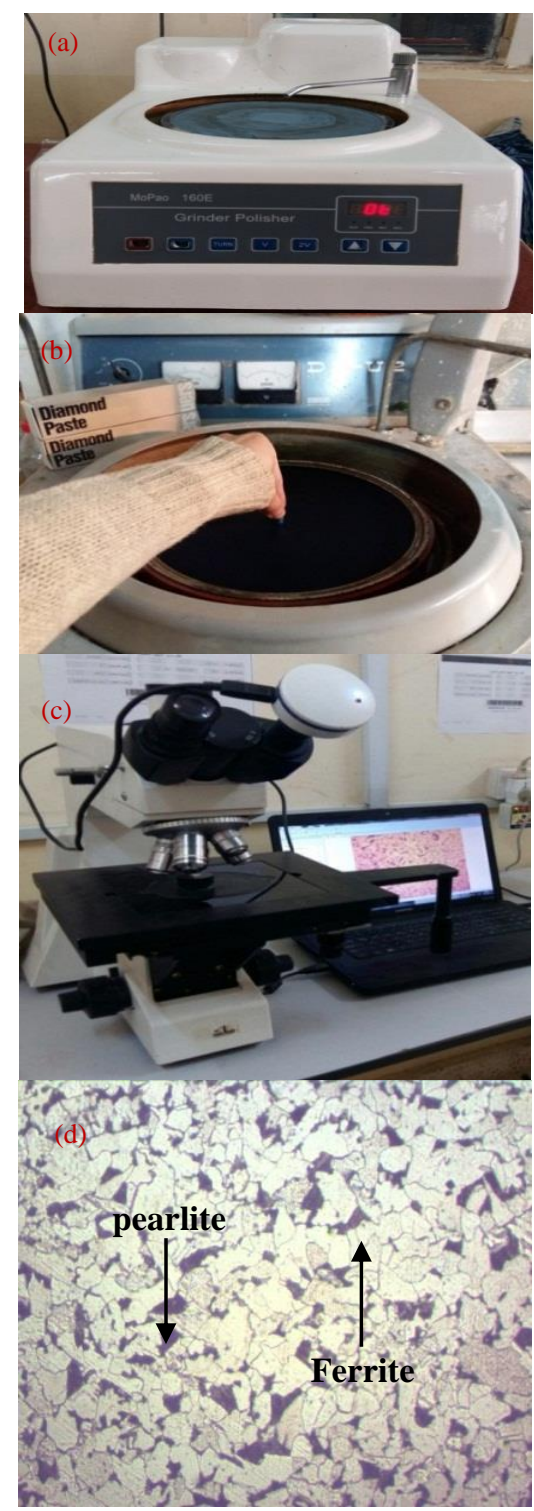

Fig. 3. a) Grinding device b) Polishing device c)Optical microscope device d) Microstructure of low carbon steel

\section{B. Burnishing process}

The specimens applied in this study are treated with burnishing tool and the operation is accomplished via using lathe machine as explained in Fig. 4. In burnishing process two variables were used; these were burnishing feed and burnishing speed. The operation is done on 20 corrosion samples. The first group consists of fixed burnishing speed and change burnishing feed, where the speed was $125 \mathrm{rpm}$ and the feed was $0.6,0.9,1.5,2$ and $3 \mathrm{~mm} / \mathrm{rev}$. The second group consists of fixed burnishing feed and change burnishing speed, where the feed was $2 \mathrm{~mm} / \mathrm{rev}$ and the speed was $85,125,370,800$ and $1200 \mathrm{rpm}$. 


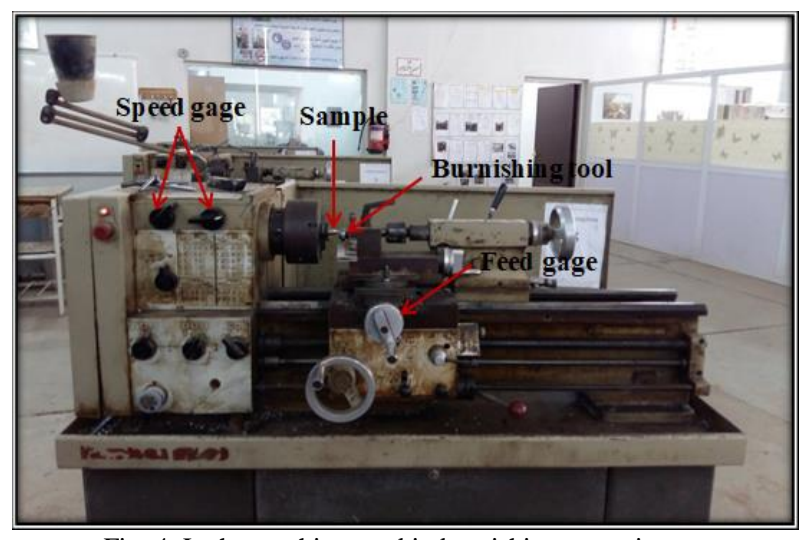

Fig. 4. Lathe machine used in burnishing operation

\section{Preparations of Corrosion samples}

Corrosion sample was very small and it was impossible to make burnishing process on it, so to prepare the standard sample for corrosion test in addition to making the burnishing on it we need to:

1. Reducing metal shafts diameter to $10 \mathrm{~mm}$ (standard diameter for corrosion sample).

2. Carrying out the burnishing technique for shafts via using conventional lathe as explained in Fig. 5.

3. Cutting rods to a length of $12 \mathrm{~mm}$ in order to prepare the corrosion samples, then drilling samples with diameter of $\phi 2.5 \mathrm{~mm}$ and then threaded to $3 \mathrm{M}$.

4. Finally, samples were cleaned by using acetone before test as indicated in Fig. 6.

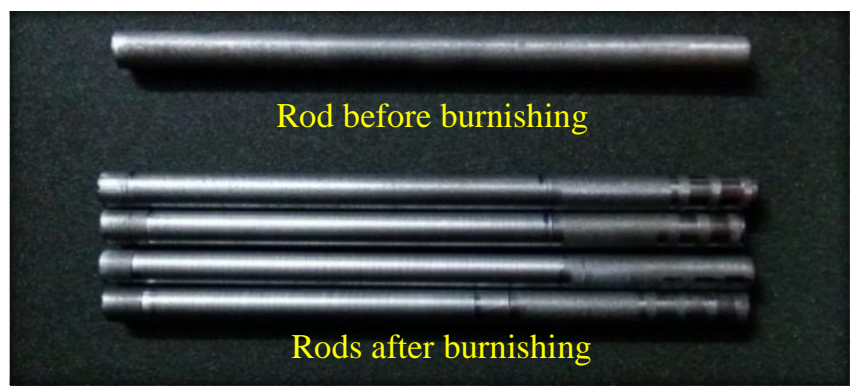

Fig. 5. Rods before and after burnishing operation

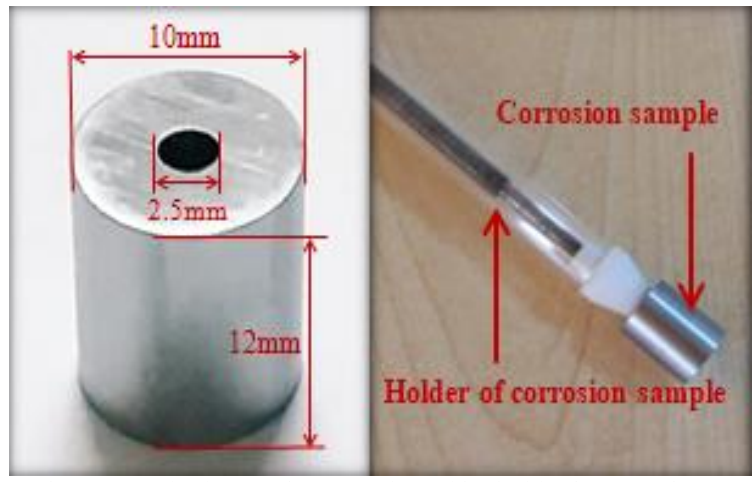

Fig. 6. Standard corrosion sample and its holder in potentiostat

\section{Choose corrosive mediums}

To investigate the corrosion resistance of low carbon steel, two different mediums were selected as indicated in Table II, these were
1. Sample of water from Tigress River at upstream Samara'a barrage, this water contain very low amount of salt.

2. Sample of water from groundwater (Yousifia salt well $90 \mathrm{~m}$ below ground surface), this water contain very high amount of salt which is about twice the salt present in sea water.

TABLE II: CHEMICAL ANALYSIS OF WATER SAMPLES

\begin{tabular}{|c|c|c|}
\hline Type of Analysis & Samara'a barrage & Yousifia salt well \\
\hline pH & 7.3 & 8 \\
\hline $\mathbf{E C}(\mu \mathrm{s} / \mathrm{Cm})$ & 440 & 9430 \\
\hline T.D.S (mg/l) & 296 & 6100 \\
\hline $\mathrm{Ca}^{+2}(\mathrm{mg} / \mathrm{l})$ & 28 & 445 \\
\hline $\mathrm{Na}^{+}(\mathbf{m g} / \mathbf{l})$ & 46 & 762 \\
\hline $\mathrm{Cl}^{-}(\mathrm{mg} / \mathrm{l})$ & 85 & 998 \\
\hline $\mathrm{HCO}_{3}^{-}(\mathrm{mg} / \mathrm{l})$ & 18 & 611 \\
\hline $\mathrm{SO}_{4}{ }^{2-}(\mathrm{mg} / \mathrm{l})$ & 78 & 1643 \\
\hline $\mathrm{Mg}^{2+}(\mathrm{mg} / \mathrm{l})$ & 16 & 200 \\
\hline $\mathrm{K}^{+}(\mathrm{mg} / \mathrm{l})$ & 2 & 25 \\
\hline $\mathrm{NO}_{3}^{-}(\mathrm{mg} / \mathrm{l})$ & 2 & 2 \\
\hline $\mathrm{CO}_{3}^{2-}(\mathrm{mg} / \mathrm{l})$ & 0 & 0 \\
\hline
\end{tabular}

\section{CORROSION TEST}

Corrosion test was applied to measure the rate of corrosion for the specimens via applying Gamry series (G300) potentiostat device which present in the computer as indicate in Fig. 7, the experiments carried out by Tafel test. This test was occurred for both corrosive mediums at room temperature $\left(23^{\circ} \mathrm{C}\right)$.

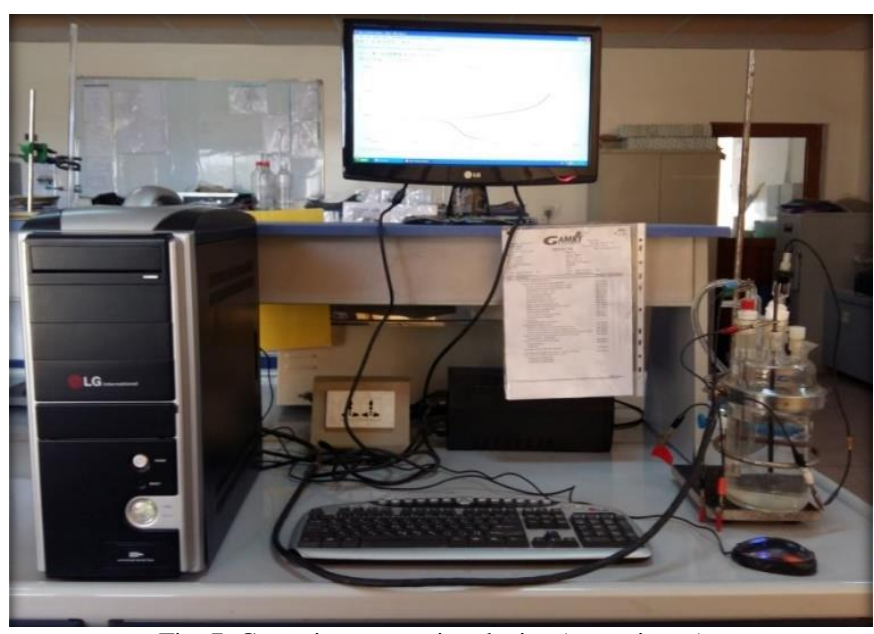

Fig. 7. Corrosion measuring device (potentiostat)

The device consisted of 3 electrodes as indicate in Fig. 8: The first one was the working electrode (W.E) and its sample name that is being tested, the second one is the graphite and it is applied as an auxiliary electrode, the third one is a Saturated calomel electrode (standard electrode). The data and results will appear on the screen monitor via Gamry software (program Echem analyst) which shows corrosion rate data and curves. 


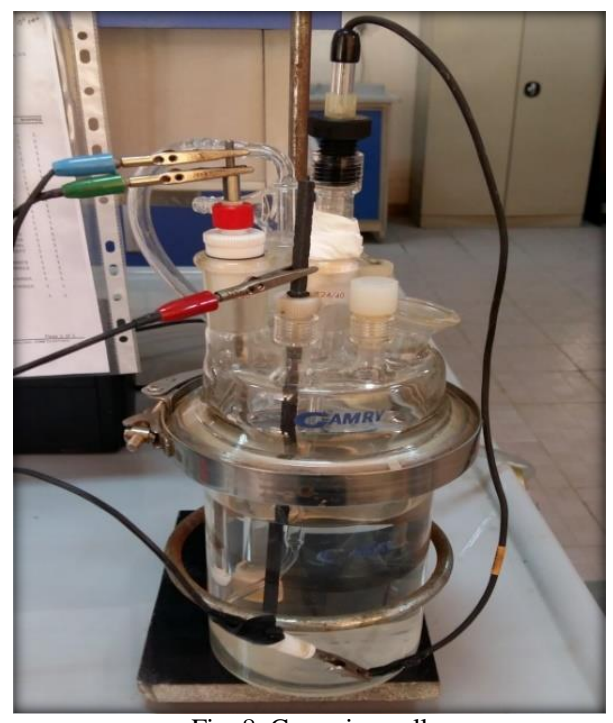

\section{A. Electrochemical polarization tests in water sample from upstream Samara'a barrage}

The corrosion test was done on (AISI 1017) steel before and after burnishing operation. This test was done in a sample of water from upstream samara'a barrage at room temperature $\left(23^{\circ} \mathrm{C}\right)$. Fig. 9 and 10 indicate Tafel tests for steel specimens in this water. It is clear that there are slight differences in cathodic reactions, fastest cathodic reaction was for the sample without making burnishing operation on it which means it has the highest corrosion rate, while the slowest reaction was for sample that cold worked with burnishing operation with a feed of $2 \mathrm{~mm} / \mathrm{rev}$ and speed of $1200 \mathrm{rpm}$, this means that it has the lowest corrosion rate.

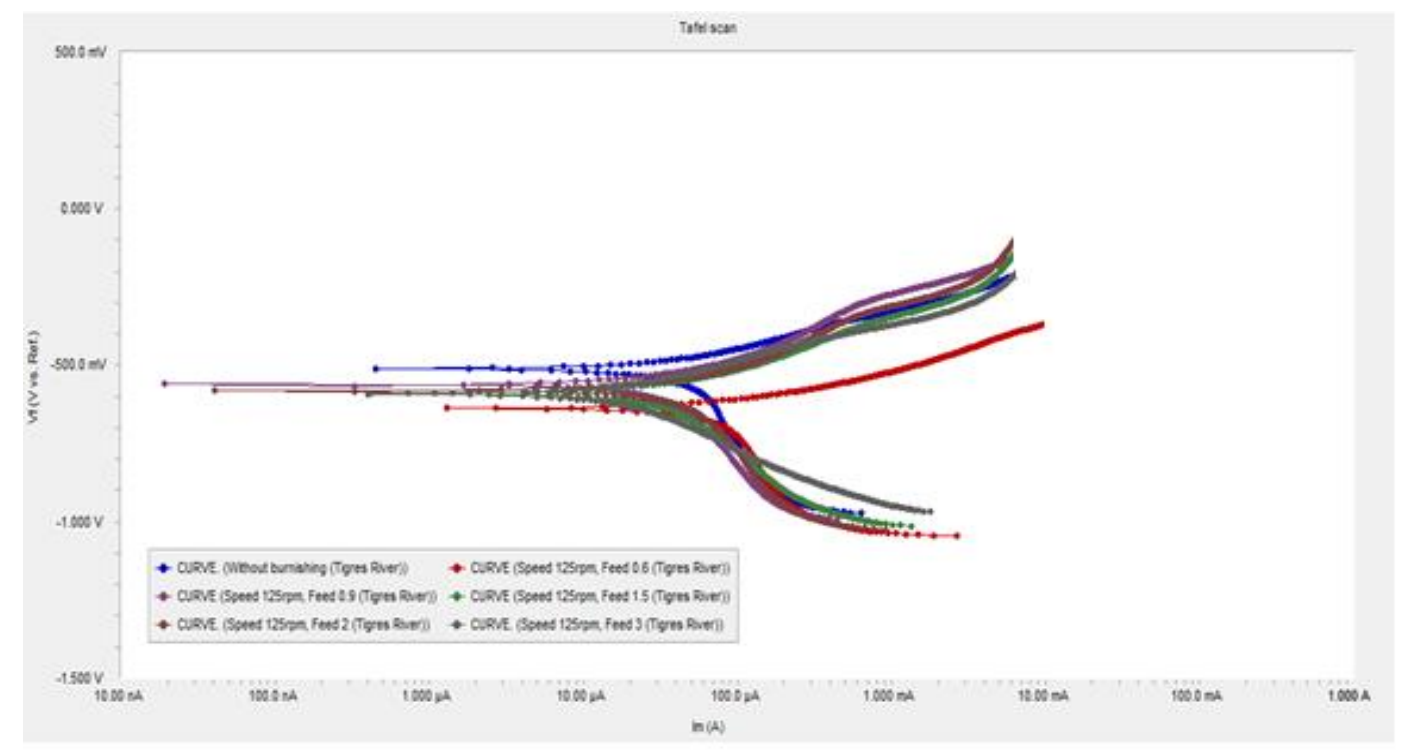

Fig. 9. Tafel tests for (AISI 1017) steel in water sample from Tigress river before burnishing and after burnishing operation when the speed was held at $125 \mathrm{rpm}$ and the feed was changed at $(0.6,0.9,1.5,2,3 \mathrm{~mm} / \mathrm{rev})$

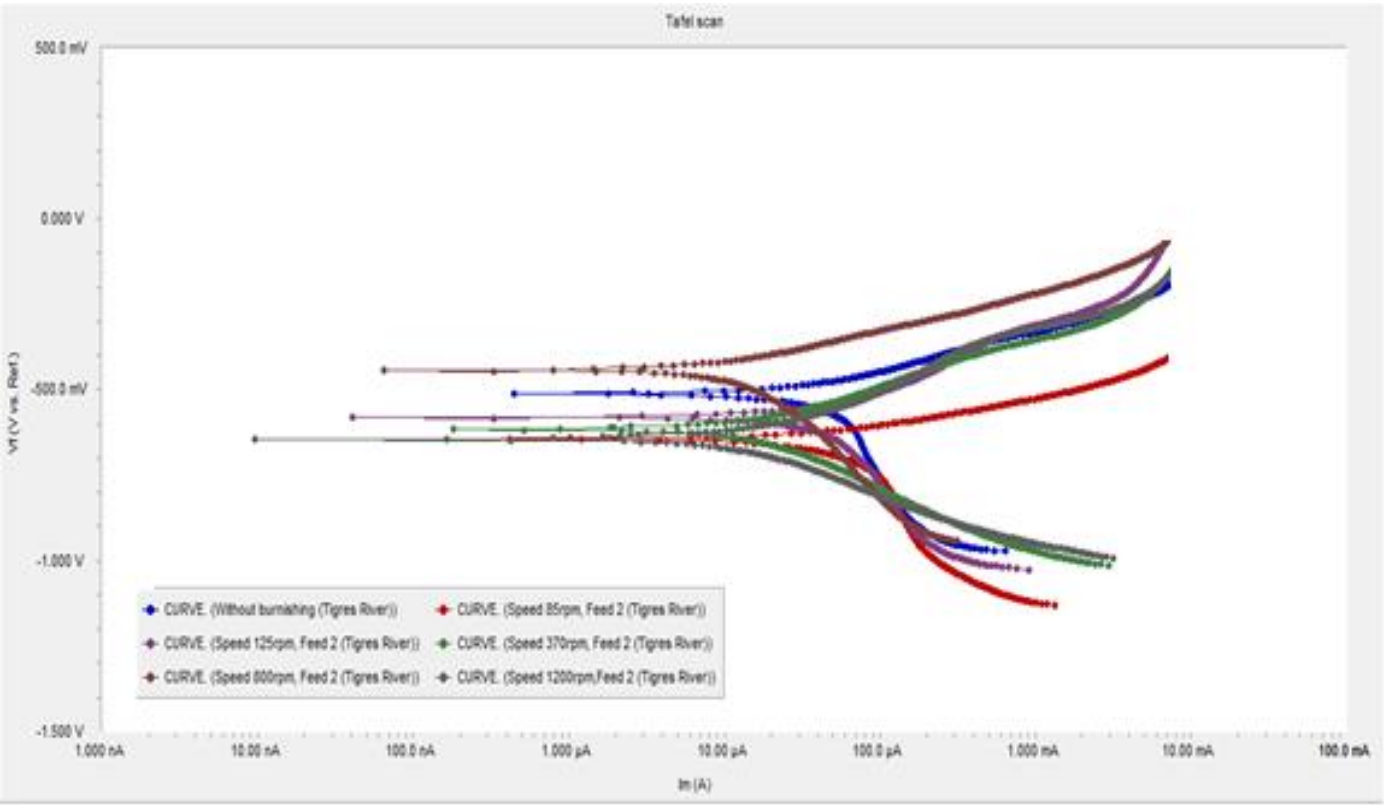

Fig. 10. Tafel tests for (AISI 1017) steel in water sample from Tigress river before burnishing operation and after burnishing operation when the feed was held at $2 \mathrm{~mm} / \mathrm{rev}$ and the speed was changed at $(85,125,370,800,1200 \mathrm{rpm})$ 
It was clear that when the burnishing feed increase, the corrosion rate decreased until reach to certain value, after that value, the corrosion resistance improved but at value lower than the highest value that was obtained as indicated in Table III, this perhaps due to the lapping formation which perhaps induce corrosion initiators or porosity.

TABLE III: THE RESUltS OF CORROSION TESTS IN TIGRESS RIVER BEFORE

\begin{tabular}{lccc}
\multicolumn{3}{c}{ AND AFTER BURNISHING OPERATION (CHANGING FEED) } \\
\hline \hline Sample & $\begin{array}{c}\mathbf{I}_{\text {corr }} \\
(\boldsymbol{\mu A})\end{array}$ & $\begin{array}{c}\mathbf{E}_{\text {corr }} \\
(\mathbf{m V})\end{array}$ & $\begin{array}{c}\text { Corr. Rate } \\
(\mathbf{m p y})\end{array}$ \\
\hline $\begin{array}{l}\text { Without burnishing } \\
\text { Speed 125rpm, feed 0.6 } \\
\text { mm/rev }\end{array}$ & 87.60 & -511.0 & 7.577 \\
$\begin{array}{l}\text { Speed 125rpm, feed 0.9 } \\
\text { mm/rev }\end{array}$ & 87.10 & -637 & 7.528 \\
$\begin{array}{l}\text { Speed 125rpm, feed 1.5 } \\
\text { mm/rev }\end{array}$ & 47.8 & -560.0 & 4.132 \\
$\begin{array}{l}\text { Speed 125rpm, feed 2 } \\
\text { mm/rev }\end{array}$ & 19.90 & -589.0 & 3.798 \\
$\begin{array}{l}\text { Speed 125rpm, feed 3 } \\
\text { mm/rev }\end{array}$ & 23.5 & -579 & 1.712 \\
\hline \hline
\end{tabular}

And when increasing burnishing speed, the corrosion rate decrease until reach to the lowest value of corrosion rate which means better corrosion resistance obtained as indicate in Table IV, this is because of the plastic deformation on the surface, where there was rearrangement of the grains at the surface of the steel because of the cold working operation.
TABLE IV: THE RESUlTS OF CORROSION TESTS IN TIGRESS RIVER BEFORE AND AFTER BURNISHING OPERATION (CHANGING SPEED)

\begin{tabular}{lccc}
\hline \hline Sample & $\begin{array}{c}\mathbf{I}_{\text {corr }} \\
(\boldsymbol{\mu A})\end{array}$ & $\begin{array}{c}\mathbf{E}_{\text {corr }} \\
(\mathbf{m V})\end{array}$ & $\begin{array}{c}\text { Corr. Rate } \\
(\mathbf{m p y})\end{array}$ \\
\hline $\begin{array}{l}\text { Without burnishing } \\
\text { Speed 85rpm, feed 2 } \\
\text { mm/rev }\end{array}$ & 87.60 & -511.0 & 7.577 \\
$\begin{array}{l}\text { Speed 125rpm, feed 2 } \\
\text { mm/rev }\end{array}$ & 25.6 & -642.0 & 2.345 \\
$\begin{array}{l}\text { Speed 370rpm, feed 2 } \\
\text { mm/rev }\end{array}$ & 19.8 & -579 & 1.712 \\
$\begin{array}{l}\text { Speed 800rpm, feed 2 } \\
\text { mm/rev }\end{array}$ & 18.8 & -614.0 & 1.624 \\
$\begin{array}{l}\text { Speed 1200rpm, feed 2 } \\
\text { mm/rev }\end{array}$ & 10.40 & -440.0 & 0.898 \\
\hline \hline
\end{tabular}

B. Electrochemical polarization tests in water sample from groundwater sample (Yousifia salt well $90 \mathrm{~m}$ below ground surface)

The corrosion test was done on the (AISI 1017) steel before and after burnishing operation. This test was done in a sample of water from groundwater (Yousifia salt well $90 \mathrm{~m}$ below ground surface) at room temperature $\left(23^{\circ} \mathrm{C}\right)$. Fig. 11 and 12 indicate Tafel tests for steel specimens in this water. It is clear that there are slight differences in cathodic reactions, fastest cathodic reaction was for the sample without making burnishing operation on it which means it has the highest corrosion rate, while the slowest reaction was in the test of sample that cold worked with burnishing operation at a feed of $2 \mathrm{~mm} / \mathrm{rev}$ and speed of $1200 \mathrm{rpm}$, this means that it has the lowest corrosion rate.

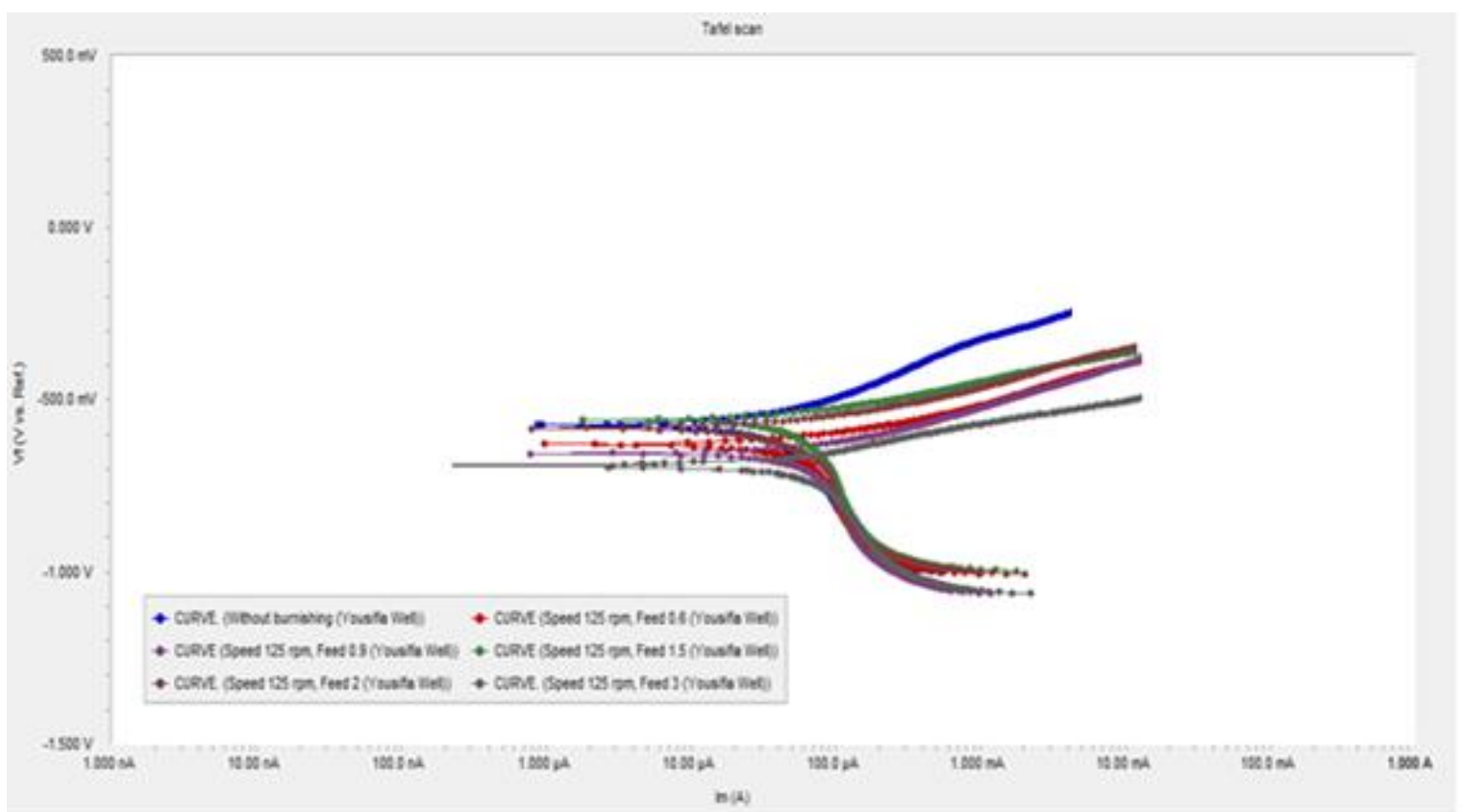

Fig. 11. Tafel tests for (AISI 1017) steel in water sample from groundwater before burnishing and after burnishing operation when the speed was hold at $125 \mathrm{rpm}$ and the feed was changed at $(0.6,0.9,1.5,2,3 \mathrm{~mm} / \mathrm{rev})$ 


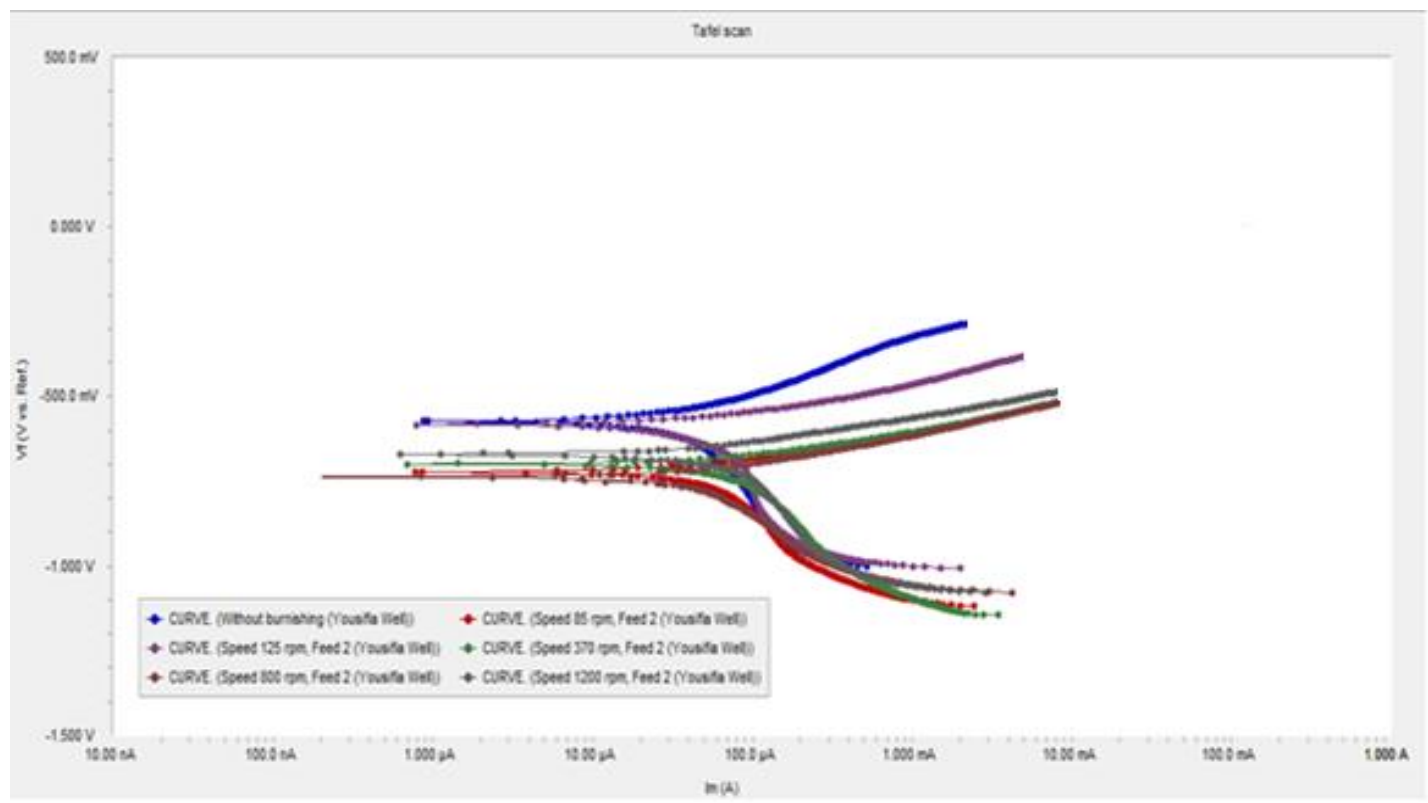

Fig. 12. Tafel tests for (AISI 1017) steel in water sample from groundwater before burnishing operation and after burnishing operation when the feed was hold at $2 \mathrm{~mm} / \mathrm{rev}$ and the speed was changed at $(85,125,370,800,1200 \mathrm{rpm})$

It is clear that when the burnishing feed increase, the corrosion rate decreased until reach to certain value, after that value, the corrosion resistance improved but at value lower than the highest value that was obtained as indicated in Table V.

TABLE V: THE RESUlTS OF CORROSION TESTS IN WATER SAMPLE FROM GROUNDWATER BEFORE AND AFTER BURNISHING OPERATION (VARIABLE

\begin{tabular}{|c|c|c|c|}
\hline \multicolumn{4}{|c|}{ FEED) } \\
\hline Sample & $\begin{array}{l}\mathbf{I}_{\text {corr }} \\
(\boldsymbol{\mu A})\end{array}$ & $\begin{array}{l}\mathbf{E}_{\text {corr }} \\
(\mathbf{m V})\end{array}$ & $\begin{array}{l}\text { Corr. Rate } \\
\text { (mpy) }\end{array}$ \\
\hline Without burnishing & 103.0 & -572.0 & 8.878 \\
\hline $\begin{array}{c}\text { Speed 125rpm, feed } 0.6 \\
\mathrm{~mm} / \mathrm{rev}\end{array}$ & 79.80 & -629 & 6.903 \\
\hline $\begin{array}{c}\text { Speed 125rpm, feed } 0.9 \\
\mathrm{~mm} / \mathrm{rev}\end{array}$ & 73.80 & -655.0 & 6.382 \\
\hline $\begin{array}{c}\text { Speed 125rpm, feed } 1.5 \\
\mathrm{~mm} / \mathrm{rev}\end{array}$ & 51.80 & -557.0 & 4.477 \\
\hline $\begin{array}{c}\text { Speed 125rpm, feed } 2 \\
\text { mm/rev }\end{array}$ & 39.00 & -582 & 3.368 \\
\hline $\begin{array}{l}\text { Speed 125rpm, feed } 3 \\
\text { mm/rev }\end{array}$ & 43.90 & -691.0 & 3.794 \\
\hline
\end{tabular}

And when increasing burnishing speed, the corrosion rate decreased until reach to the lowest value of corrosion rate which means better corrosion resistance obtained as indicated in Table VI, this is because of the plastic deformation on the surface, where there was increasing in dislocation density and slip bands.

TABLE VI: THE RESUlTS OF CORROSION TESTS IN SAMPLE OF WATER FROM GROUNDWATER BEFORE AND AFTER BURNISHING OPERATION

\begin{tabular}{lccc}
\multicolumn{4}{c}{ (VARIABLE SPEED) } \\
\hline \hline Sample & $\begin{array}{c}\mathbf{I}_{\text {corr }} \\
(\boldsymbol{\mu A})\end{array}$ & $\begin{array}{c}\mathbf{E}_{\text {corr }} \\
(\mathbf{m V})\end{array}$ & $\begin{array}{c}\text { Corr. Rate } \\
(\mathbf{m p y})\end{array}$ \\
\hline $\begin{array}{l}\text { Without burnishing } \\
\text { Speed 85rpm, feed 2 } \\
\text { mm/rev }\end{array}$ & 103.0 & -572.0 & 8.878 \\
$\begin{array}{l}\text { Speed 125rpm, feed 2 } \\
\text { mm/rev }\end{array}$ & 47.60 & -721.0 & 4.114 \\
$\begin{array}{l}\text { Speed 370rpm, feed 2 } \\
\text { mm/rev }\end{array}$ & 39.00 & -582 & 3.368 \\
$\begin{array}{l}\text { Speed 800rpm, feed 2 } \\
\text { mm/rev }\end{array}$ & 38.4 & -699.0 & 3.324 \\
$\begin{array}{l}\text { Speed 1200rpm, feed 2 } \\
\text { mm/rev }\end{array}$ & 34.4 & -738.0 & 2.971 \\
\hline \hline
\end{tabular}

\section{Chemical analysis of corrosive mediums}

After the test of corrosion, the sample of water was analysis chemically to find the parameter that helped to corrode the metal. The first 8 parameters in Table VII is the reason for the corrosion of low carbon steel in these media and that was clear by comparing the values of each parameter before and after corrosion. $\mathrm{Cl}^{-}, \mathrm{Ca}^{+2}$ and $\mathrm{SO}_{4}{ }^{2-}$ were the most corrosive parameters which lead to the corrosion of the metal.

TABLE VII: CHEMICAL ANALYSIS OF WATER SAMPLES

\begin{tabular}{|c|c|c|c|c|}
\hline \multirow{2}{*}{$\begin{array}{l}\text { Type of } \\
\text { Analysis }\end{array}$} & \multicolumn{2}{|c|}{ Samara'a barrage } & \multicolumn{2}{|c|}{ Yousifia salt well } \\
\hline & $\begin{array}{c}\text { Before } \\
\text { corrosion }\end{array}$ & $\begin{array}{c}\text { After } \\
\text { corrosion }\end{array}$ & $\begin{array}{c}\text { Before } \\
\text { corrosion }\end{array}$ & $\begin{array}{c}\text { After } \\
\text { corrosion }\end{array}$ \\
\hline $\mathrm{pH}$ & 7.3 & 7.24 & 8 & 7.9 \\
\hline $\mathrm{EC}(\mu \mathrm{s} / \mathrm{Cm})$ & 440 & 572 & 9430 & 10400 \\
\hline T.D.S (mg/l) & 296 & 383 & 6100 & 7000 \\
\hline $\mathrm{Ca}^{+2}(\mathrm{mg} / \mathrm{l})$ & 28 & 38 & 445 & 480 \\
\hline $\mathrm{Na}^{+}(\mathrm{mg} / \mathrm{l})$ & 46 & 50 & 762 & 783 \\
\hline $\mathrm{Cl}^{-}(\mathrm{mg} / \mathrm{l})$ & 85 & 95 & 998 & 1043 \\
\hline $\mathrm{HCO}_{3}^{-}(\mathrm{mg} / \mathrm{l})$ & 18 & 20 & 611 & 671 \\
\hline $\mathrm{SO}_{4}{ }^{2-}(\mathrm{mg} / \mathrm{l})$ & 78 & 112 & 1643 & 1718 \\
\hline $\mathrm{Mg}^{2+}(\mathrm{mg} / \mathrm{l})$ & 16 & 16 & 200 & 210 \\
\hline $\mathrm{K}^{+}(\mathbf{m g} / \mathbf{l})$ & 2 & 2 & 25 & 30 \\
\hline $\mathrm{NO}_{3}^{-}(\mathrm{mg} / \mathrm{l})$ & 2 & 2 & 2 & 2 \\
\hline $\mathrm{CO}_{3}^{2-}(\mathrm{mg} / \mathrm{l})$ & 0 & 0 & 0 & 0 \\
\hline
\end{tabular}

\section{CONCLUSION}

Burnishing operation which done on low carbon steel (AISI 1017) caused improvement in the corrosion resistance of the steel and this improvement abstracted in the following points:

1. From the comparison between the two different mediums it was evident that the water sample from 
the salt groundwater was more corrosive than the samples of water from Tigress River.

2. Increasing feed of burnishing lead to enhancement in corrosion resistance, where the rate of corrosion lowered until reach to certain value after that value the corrosion rate reduced but at value higher than the better value which obtain.

3. Increasing speed of burnishing lead to enhancement in corrosion resistance, where the rate of corrosion lowered with increasing speed of burnishing.

4. The better improvement in corrosion resistance was at feed of $2 \mathrm{~mm} / \mathrm{rev}$ and speed of $1200 \mathrm{rpm}$, where the corrosion rate reduced from $7.577 \mathrm{mpy}$ to $0.685 \mathrm{mpy}$ in water sample of Tigress river and from $8.878 \mathrm{mpy}$ to $1.380 \mathrm{mpy}$ in water sample of salt groundwater.

\section{REFERENCES}

[1] William D. Callister, Jr., "Material Science and Engineering", (2003), pp.570, United State of America, John Wiley \& Sons, Inc., sixth edition.

[2] E.E. Stansbury and R.A. Buchanan, "Fundamental of electrochemical and corrosion", (2000), p.1, United State of America, ASM International.

[3] Al-Sultani Kadhim F., Alseroury F. A., Duaa A. Ali, "Use EcoFriendly Materials to Steel Corrosion Inhibition", International Journal of Advances in Science Engineering and Technology, (2016), Volume 4, Issue 4, pp.40-44.

[4] Yuantai Ma et al., "Corrosion of low carbon steel in atmospheric environments of different chloride content", Journal of corrosion science at science direct, 51 (2009), pp. 997-1006.

[5] Michael Ashby, Hugh Shercliff and David Cebon, "Materials, engineering, science, processing and design", (2007), p.390, UK, Elsevier.

[6] Junwen Tang et al., "Corrosion behavior of carbon steel in different concentrations of $\mathrm{HCl}$ solutions containing $\mathrm{H}_{2} \mathrm{~S}$ at $90^{\circ} \mathrm{C}$ ", Journal of corrosion science at science direct, 53 (2011), pp. 1715-1723.
[7] Kenneth G. Budinski and Michael K. Budinski, "Engineering Materials, properties and selection", (2010), p.393-434, New Jersey, Pearson Education.

[8] Osarolube et al., "Corrosion behavior of mild and high carbon steels in various acidic media", Journal of Scientific Research and Essay, June (2008), Vol.3 (6), pp. 224-228.

[9] J. Dossett and G.E. Totten, "Steel Heat Treating Fundamentals and Processes", (2013), p.2- 259, United State of America, ASM International, Volume 4A.

[10] Ibrahim A.A. et al., " Study the influence of a new ball burnishing technique on the surface roughness of AISI 1018 low carbon steel", International Journal of Engineering \& Technology (2015), Vol 4 (1), pp. 227-232.

[11] Deepak Mahajan and Ravindra Tajane, "A Review on Ball Burnishing Process", International Journal of Scientific and Research Publications, (2013), Volume 3, Issue 4, p.1-8.

[12] Murali Krishna R., "An investigation of the effect of the process parameters on the material properties of burnished components", Thesis (Doctor), July (2012), Faculty of Mechanical Engineering, Hyderabad University, India.

[13] Ashutosh Verma and Dalgobind Mahato, "Roller Burnishing-A Literature Review of Developments and Trends in Approach to Industrial Application", Asian Journal of Engineering and Technology, (2013), Volume 01, Issue 03, p.68-83.

[14] Tadeusz Hryniewiez and Krzysztof Rokosz, " Corrosion behavior of C45 carbon steel after roller burnishing", Journal of Hradec nad Moravici (2005), Vol. 5 pp. 24-26.

[15] N. M. Qureshi, Vaibhav B. Patil, Basavaraj D. Teli, "Analysis of Effect of Ball and Roller Burnishing Processes on Surface Roughness on EN8 Steel", International Journal of Engineering Research and Technology, (2015), Volume 4, Issue 06, p.311-315.

[16] Hamadache Hamid et al.," Characterization layer hardened burnished steel AISI/SAE 3115", International Journal of Mechanics and Applications (2014), Vol. 4 (1), pp. 13-19.

[17] Davinder Saini., Manish Kapoor, C. S Jawalkar, "Parametric Analysis of Mild Steel Specimens Using Roller Burnishing Process", International Refereed Journal of Engineering and Science, (2017), Volume 6, Issue 3, p.45-51.

[18] Malleswara Rao J. N. et al., "The effect of roller burnishing on surface hardness and surface roughness on mild steel specimens", International Journal of Applied Engineering Research, Dindigul (2011), Vol. 1 No. 4. 